\title{
Risk factors and prevalence of osteoporosis in premenopausal women from poor economic backgrounds in Colombia
}

This article was published in the following Dove Press journal:

International Journal of Women's Health

18 July 2013

Number of times this article has been viewed

\author{
John Londono' \\ Paula Valencia' \\ Ana María Santos' \\ Luisa F Gutiérrez ${ }^{2}$ \\ Roberto Baquero' \\ Rafael Valle-Oñate ${ }^{1,3}$ \\ 'Rheumatology Department, \\ Universidad de La Sabana, Chía, \\ Cundinamarca, Colombia; \\ ${ }^{2}$ Preventive Care Ltd, Research \\ Unit, Chía, Cundinamarca, Colombia, \\ ${ }^{3}$ Rheumatology Department, Hospital \\ Militar Central, Bogotá, DC, Colombia
}

Correspondence: John Londono Rheumatology Department, Universidad de La Sabana, Campus del Puente del Común, Km 7, Autopista Norte de Bogotá, Chía, Cundinamarca, Colombia Tel +57 I $86 \mid 5555$

Fax +57 I 86I 56I8

Email john.londono@unisabana.edu.co
Introduction: The prevalence of osteoporosis in premenopausal women along with associated risk factors has not been well elucidated. Recent studies have shown that poverty is a risk factor for osteoporosis.

Objective: To determine the prevalence of osteoporosis and its risk factors in a group of premenopausal women of poor economic background in Colombia.

Materials and methods: The study comprised 1483 women between 35 and 53 years of age with at least one risk factor for osteoporosis. Demographic characteristics, reproductive factors, comorbidities, and risk factors for osteoporosis were evaluated. Lumbar vertebrae (L2-L4) and the femur neck were assessed using dual-energy X-ray absorptiometry.

Results: Of the 1483 patients, 1443 (97.3\%) had at least one risk factor for osteoporosis and $40(2.7 \%)$ had no risk factors. Patients with one risk factor were referred to have a dual-energy X-ray absorptiometry scan, which 795 women completed. Osteopenia was found in $30.5 \%$ and osteoporosis in $4.8 \%$ of these women. The majority of these women were homemakers, and $18.5 \%$ of the patients with osteoporosis were also illiterate $(P<0.001)$. The risk factors identified in this population were: hypothyroidism (odds ratio $[\mathrm{OR}]=5.19,95 \%$ confidence interval $[\mathrm{CI}]: 1.6-16$ ), age over 45 years old $(\mathrm{OR}=1.13,95 \% \mathrm{CI}: 1.0-1.2)$, a history of malnutrition or low birth weight $(\mathrm{OR}=2.35,95 \% \mathrm{CI}: 1.0-5.2)$, or early-onset menopause (OR $=3.4,95 \%$ CI: $1.6-7.2)$.

Conclusion: Premenopausal Colombian women from impoverished areas showed increased rates of osteopenia and osteoporosis compared with the data described in the current literature. Hypothyroidism was an outstanding risk factor in Colombian premenopausal women with osteoporosis. This shows the influence of poverty and other risk factors on the onset of osteoporosis in women aged $35-53$ years.

Keywords: osteopenia, osteoporosis, malnutrition, hypothyroidism

\section{Introduction}

The highest bone mineral density (BMD) that is reached by a fertile woman, along with other factors, can predict the occurrence of osteoporosis after menopause. Both osteopenia and osteoporosis in premenopausal women can be attributed to a low BMD during the growth period in childhood, adolescence and early adulthood or an excess loss of density after reaching peak BMD. ${ }^{1}$

After menopause, 54\% of females are considered to have osteopenia, and $30 \%$ of them could develop osteoporosis in the future. Prevalence of osteoporosis increases with age; it can range from some $5 \%$ in women of 50 years old to about $50 \%$ in women over 85 years. $^{2}$ In Latin America, the statistics are very similar, where it is estimated that $12 \%-18 \%$ of women over 50 years have osteoporosis of the spine, and about $8 \%-22 \%$ of the hip. ${ }^{3}$ 
The prevalence of osteoporosis in premenopausal women has not been well evaluated. In this study, we used the definitions of osteopenia and osteoporosis established by the World Health Organization (WHO): osteoporosis is a T-score $\leq-2.5$ standard deviations (SDs), which, in theory, means that only around $0.5 \%$ of women between the ages of 30 and 40 years will meet criteria of osteoporosis, and another $15 \%$ will be described as having osteopenia (T-score between -1 and $-2.5 \mathrm{SDs}$ ) in any population. ${ }^{4}$

Although risk factors for low BMD in postmenopausal women are well described, risk factors for low BMD in premenopausal women are not. There are several factors that determine if a woman will achieve an adequate BMD; among these are genes and their polymorphisms, at 50\%-80\%; ${ }^{4}$ anthropomorphic measures; hormones; lifestyle factors; and nutrition. ${ }^{5}$ Poverty is an important independent risk factor for osteoporosis and fractures, which has been brought to light recently, with studies showing that postmenopausal impoverished women had a lower BMD of the spine and a higher risk of fracture. ${ }^{5,6}$

In the United States, osteoporosis is a large problem, causing about 1.5 million fractures each year. It is considered a metabolic disease that is commonly addressed in first-world countries and less in developing countries for a multitude of reasons, including: the belief that it is exclusively a firstworld problem; the belief that it is an unavoidable problem of aging that cannot be treated or prevented; greater attention from insurance companies and politicians to other diseases; fractures with unstudied causes; poorly allocated resources; and little epidemiological data. ${ }^{6}$

There are very few studies that evaluate the presence of specific risk factors for osteoporosis and osteopenia in premenopausal women, which could prove invaluable in informing the use of preventative and treatable measures.

The objective of this study was to determine the prevalence of osteopenia and osteoporosis in a group of premenopausal women in an impoverished area, taking into account that poverty can be an important risk factor for low BMD.

\section{Materials and methods Population}

A cross-sectional descriptive analysis was done in May 2008. First, the results from the National Statistic Administrative Department of Colombia (DANE) census in 2005 were reviewed. ${ }^{7}$ This census included women from 35-53 years old living in Bogotá city, Colombia, divided by a stratification scale from 1-6 (1 being the lowest and 6 being the highest socioeconomic status). From the total number, 538,965 women, we calculated from the scale that, from a significant sample size with a power of $95 \%$ and prevalence of $7 \%$, that the population needed for the study would be 1300 women. For the study, it was concluded that 1400 would adequately satisfy the sample size needed to answer the objective.

The population studied had to have at least one risk factor for osteoporosis (family history of osteoporosis, fractures with mild trauma, loss of $3 \mathrm{~cm}$ of height, use of alcohol, smoking $>10$ cigarettes daily, history of malabsorption, history of low weight during childhood or adolescence, last menses before 45 years of age, amenorrhea of more than 6 months, abnormal libido). The patients were asked about their history of comorbidities - hypertension, diabetes, and thyroid disease - and their reproductive background. Exclusion criteria were based on whether patients had a debilitating chronic illness; a disability that affected normal physical activity; prolonged periods of immobility caused by chronic diseases; sequelae of rheumatic disease; cardiovascular disease; neurological disease; diabetes mellitus; previous surgeries that would impede a dual-energy X-ray absorptiometry (DEXA) scan (eg, articular prosthesis); treatment with calcium, vitamin $\mathrm{D}$, and/or hormones for more than 6 months; history of osteopenia/osteoporosis; or physical or mental limitations that affect their movement or ability to provide informed consent, fill out forms, or answer questions.

A total of 1483 women were identified as meeting the inclusion criteria in the absence of any exclusion criteria. Each was evaluated with a full physical exam and had their anthropomorphic measurements such as weight, height, and body mass index (BMI) taken. Each patient then filled out a survey that evaluated demographic characteristics, reproductive characteristics, and risk factors for osteoporosis. They were also asked to fill out the 12-Item Short Form Health Survey (SF-12), the Health Assessment Questionnaire (HAQ), and the Global Physical Activity Questionnaire (GPAQ).

Lumbar vertebrae (L2-L4) and the femur neck were assessed using DEXA with a prodigy advanced densitometer from General Electric Healthcare (Fairfield, CT, USA) with a coefficient of variability of results very small, because the Hispanic population used to obtain the results is comparable with the characteristics of the Colombian population.

\section{Statistical analysis}

SPSS for Windows (v 19; IBM Corporation, Armonk, NY, USA) was used for statistical analysis. The categorical 
variables were presented with frequencies and percentages, and continuous variables with mean and SDs. The $t$-test was used to compare measurements of continuous variables and Chi square for categorical variables. The Fisher exact correction was used when it was necessary. To establish the association of risk factors with diseases, we used a logistic regression analysis. $P$-value was considered significant at $<0.05$.

The following were considered independent variables to be analyzed in the logistic regression model: BMI; weight; illiteracy; history of fracture as a result of slight trauma; considered to be a physically fragile person or having reduced muscle mass; history of underweight or malnutrition; history of irregular menses of more than 6 months other than during pregnancy; history of last menses before 45 years of age; age $>45$ years; have medical history of hypothyroidism.

\section{Ethical considerations}

This study followed the principles described by the Declaration of Helsinki and all rules and regulations of the Colombian government. It was reviewed and approved by the ethics committee at La Sabana University, and all appropriate cases were sent to specialists for treatment once diagnosed with disease.

\section{Results}

Of the 1483 patients included, $1443(97.3 \%)$ had at least one risk factor for osteoporosis and $40(2.7 \%)$ had no risk factors. The 1443 patients with one risk factor were referred to have a DEXA scan, which 795 women completed. A diagnosis of osteopenia was found in $30.5 \%$ and osteoporosis in $4.8 \%$. The majority of these women were homemakers and belonged to the impoverished class (stratification scale 1) in Colombia, and $18.5 \%$ of the 38 patients with osteoporosis were also illiterate $(P<0.001)$. There were no differences across race or occupation. Table 1 outlines the demographic characteristics of the population studied.

Table 2 shows the obstetric and gynecological history (normal versus osteoporotic, respectively), number of gestations ( $3.4 \pm 1.8$ vs $3.6 \pm 2.4, P=0.6)$, and births $(2.9 \pm 1.5$ vs $2.8 \pm 1.7, P=0.7)$. The other number worthy of mention is the presence of hypothyroidism of women with osteoporosis (13.1\%) versus unaffected individuals (4.8\%), which was statistically significant at $P=0$.

Low muscle mass, history of a low birth or childhood weight, or family history of early-onset menopause are all risk factors for osteoporosis according to our univariate analysis, as shown in Table 3.
Table I Demographic characteristics of the study population

\begin{tabular}{|c|c|c|c|}
\hline Characteristics & Normal & Osteoporosis & $P$-value ${ }^{a}$ \\
\hline Diagnosis & $515(64.7)$ & $38(4.8)$ & \\
\hline Osteopenia & $242(30.5)$ & & \\
\hline Age (years) & $44.7 \pm 5.5$ & $47.5 \pm 6.1$ & \\
\hline $35-40$ & $205(27)$ & $5(13)$ & \\
\hline $4 I-45$ & $225(30)$ & $5(13)$ & \\
\hline $46-53$ & 327 (43) & $28(74)$ & \\
\hline Total & $757(100)$ & $38(100)$ & 0.001 \\
\hline \multicolumn{4}{|l|}{ Education } \\
\hline Literate & 737 (97.3) & 31 (8I.5) & \\
\hline Illiterate & $20(2.7)$ & $7(18.5)$ & 0.001 \\
\hline \multicolumn{4}{|l|}{ Occupation } \\
\hline Homemaker & $484(64)$ & $28(74)$ & 0.16 \\
\hline Employed & $227(30)$ & $8(2 I)$ & \\
\hline Unemployed & $46(6)$ & $2(5)$ & \\
\hline \multicolumn{4}{|l|}{ Race } \\
\hline Mestizo & $315(4 \mid .6)$ & $19(50.6)$ & \\
\hline White & $430(56.8)$ & 18 (46.9) & 0.2 \\
\hline Black & $12(1.6)$ & I (2.5) & \\
\hline
\end{tabular}

Notes: ap-value for Fisher's exact test. Data are presented as $N(\%)$ or mean \pm standard deviation.

Patients with osteoporosis had a lower BMI and lower body weight than healthy patients $(P=0.02)$, which was further reinforced by the data seen with low weight versus other weights $(P=0.000)$, but there was no statistical difference with regards to height (Table 4). No significant difference was seen with regards to physical activity in the GPAQ questionnaire. Both unaffected women and those with osteoporosis had sedentary lifestyles in this population $(61 \%$ vs $68 \%$, respectively; $P=0.05$ ).

With respect to the SF-12 questionnaire, there was no significant difference between physical and mental components.

A multivariate analysis found that the studied sample had a higher risk for osteoporosis if they were older than 45 years (odds ratio $[\mathrm{OR}]=1.13,95 \%$ confidence interval [CI]: $1.0-1.2, P=0.003$ ) or had a history of malnutrition or low birth weight $(\mathrm{OR}=2.3595 \% \mathrm{CI}: 1.0-5.2, P=0.03)$, family history of early-onset menopause (OR $=3.4,95 \%$ CI: $1.6-7.2, P=0.001$ ), or hypothyroidism at the time of

Table 2 Patient history and comorbidities

\begin{tabular}{llll}
\hline History & Normal & Osteoporosis & P-value $^{\text {a }}$ \\
\hline Hypertension & $109(14.3)$ & $7(18.4)$ & 0.5 \\
Hypothyroidism & $37(4.8)$ & $5(13.1)$ & 0.02 \\
Hyperthyroidism & $6(0.8)$ & 0 & 0.5 \\
Number of pregnancies & $3.4 \pm 1.8$ & $3.6 \pm 2.4$ & 0.6 \\
Number of births & $2.9 \pm 1.5$ & $2.8 \pm 1.7$ & 0.7 \\
\hline
\end{tabular}

Notes: ap-value for Fisher's exact test. Data are presented as $\mathrm{N}$ (\%) or mean \pm standard deviation. 
Table 3 Risk factors surveyed

\begin{tabular}{|c|c|c|c|}
\hline \multirow[t]{2}{*}{ Risk factor } & \multicolumn{2}{|l|}{$\mathbf{N}(\%)$} & \multirow[t]{2}{*}{$P$-value ${ }^{a}$} \\
\hline & Normal & Osteoporosis & \\
\hline $\begin{array}{l}\text { History of diagnosis of } \\
\text { osteoporosis in any parent or } \\
\text { grandparent }\end{array}$ & $20 \mathrm{I}(26.5)$ & $9(23.6)$ & 0.69 \\
\hline $\begin{array}{l}\text { History of hip fracture in any } \\
\text { parent or grandparent }\end{array}$ & $140(18.4)$ & $5(13.1)$ & 0.4 \\
\hline $\begin{array}{l}\text { History of fracture as a } \\
\text { result of slight trauma }\end{array}$ & $176(23.2)$ & $12(31.5)$ & 0.23 \\
\hline $\begin{array}{l}\text { Background of reduced } \\
\text { height by } 3 \mathrm{~cm} \text { or more } \\
\text { in recent years }\end{array}$ & $308(40.6)$ & $14(36.8)$ & 0.63 \\
\hline $\begin{array}{l}\text { History of excess alcohol } \\
\text { consumption }\end{array}$ & $54(7.1)$ & $2(5.2)$ & 0.66 \\
\hline $\begin{array}{l}\text { History of consumption } \\
\text { of more than } 10 \text { cigarettes } \\
\text { a day }\end{array}$ & $74(9.8)$ & $5(13.1)$ & 0.49 \\
\hline $\begin{array}{l}\text { History of frequent episodes } \\
\text { of diarrhea }\end{array}$ & 146 (19.2) & $8(2 I)$ & 0.78 \\
\hline $\begin{array}{l}\text { Considered to be a physically } \\
\text { fragile person or having } \\
\text { reduced muscle mass }\end{array}$ & $249(32.8)$ & $34(89.4)$ & 0.01 \\
\hline $\begin{array}{l}\text { History of underweight or } \\
\text { malnutrition }\end{array}$ & $228(30)$ & $19(50)$ & 0.01 \\
\hline $\begin{array}{l}\text { History of last menses } \\
\text { before } 45 \text { years of age }\end{array}$ & 195 (25.7) & $19(50)$ & 0.001 \\
\hline $\begin{array}{l}\text { History of irregular menses } \\
\text { of more than } 6 \text { months } \\
\text { other than during pregnancy }\end{array}$ & $174(23)$ & $12(31.5)$ & 0.22 \\
\hline $\begin{array}{l}\text { History of hormonal } \\
\text { problems or decreased libido }\end{array}$ & $374(49.4)$ & $16(42)$ & 0.38 \\
\hline
\end{tabular}

Note: ${ }^{a}$-value for Fisher's exact test.

this study $(\mathrm{OR}=5.19,95 \% \mathrm{CI}: 1.6-16, P=0.005)$, which is shown in Table 5.

\section{Discussion}

This cross-sectional study comprised a very large group of premenopausal Colombian women from poor economic backgrounds to determine the prevalence of osteopenia and osteoporosis and its major risk factors.

Table 4 Nutritional state

\begin{tabular}{llll}
\hline Characteristic & \multicolumn{2}{c}{$\mathbf{N}(\%)$} & P-value $^{\mathbf{a}}$ \\
\cline { 2 - 3 } & Normal & Osteoporosis & \\
\hline Body mass index & & & \\
Low: $<18.5 \mathrm{~kg} / \mathrm{m}^{2}$ & $8(\mathrm{I} .0)$ & $2(5.3)$ & 0.02 \\
$\quad$ Normal: $18.5-24.9 \mathrm{~kg} / \mathrm{m}^{2}$ & $240(32)$ & $19(50)$ & \\
$\quad$ Overweight: $25-29.9 \mathrm{~kg} / \mathrm{m}^{2}$ & $303(40)$ & $15(39.4)$ & \\
$\quad$ Obese: $\geq 30 \mathrm{~kg} / \mathrm{m}^{2}$ & $206(27)$ & $2(5.3)$ & \\
Weight & $62.8 \pm 11.6$ & $55.8 \pm 8.7$ & 0.000 \\
Height & $151.3 \pm 5.8$ & $149.7 \pm 5.7$ & 0.1 \\
\hline
\end{tabular}

Notes: ${ }^{\text {a }}$-value for Fisher's exact test. Data are presented as $N(\%)$ or mean \pm standard deviation.
Table 5 Multivariate analysis

\begin{tabular}{|c|c|c|c|}
\hline Risk factor ${ }^{a}$ & Odds ratio & $\begin{array}{l}\text { Confidence } \\
\text { interval }\end{array}$ & $P$-value \\
\hline Age $>45$ years & 1.13 & $1.0-1.2$ & 0.003 \\
\hline $\begin{array}{l}\text { History of low weight or } \\
\text { history of malnourishment }\end{array}$ & 2.35 & $1.0-5.2$ & 0.03 \\
\hline $\begin{array}{l}\text { History of last menses before } \\
45 \text { years of age }\end{array}$ & 3.41 & $1.6-7.2$ & 0.001 \\
\hline $\begin{array}{l}\text { Personal history of } \\
\text { hypothyroidism }\end{array}$ & 5.19 & $1.6-16.2$ & 0.005 \\
\hline
\end{tabular}

Notes: andependent variables analyzed: body mass index; weight; illiteracy; history of fracture as a result of slight trauma; considered to be a weak person or with reduced muscle mass; history of underweight or malnutrition; history of irregular menses of more than 6 months other than during pregnancy; history of last menses before 45 years of age; age $>45$ years; antecedent of hypothyroidism. P-value for Chi square test.

Our study found a prevalence of osteoporosis of $4.8 \%$ and osteopenia of $30.5 \%$, which is higher than the theoretically expected figure for premenopausal women $(0.5 \%$ and $15 \%$, respectively). ${ }^{4} \mathrm{~A}$ previous study done in a similar demographic of 579 premenopausal women from 20-44 years old in Spain found a different distribution of osteopenia and osteoporosis in the spine ( $0.3 \%$ and $13.1 \%$, respectively) and the hip $(0.2 \%$ and $12.6 \%$, respectively). ${ }^{8} \mathrm{~A}$ more recent study with a sample size of 282 premenopausal women (average age of 34.8 years without family history of osteoporosis or history of fractures) found a low prevalence of osteopenia, at $10.6 \%{ }^{9}$

Other studies have shown a high prevalence of osteoporosis in premenopausal women with certain diseases that predispose to secondary osteoporosis, such as celiac disease, ${ }^{10}$ type 1 diabetes mellitus, ${ }^{11}$ rheumatoid arthritis, ${ }^{12}$ and anorexia nervosa. ${ }^{13}$ Young adults aged 18-29 in Colombia with irregular eating, such as stopping eating for more than 24 hours or consumption of a weight-loss product, have a prevalence of secondary osteoporosis of $7.8 \%{ }^{6,14}$

Our study does, however, show similar results to the world literature with respect to risk factors for osteoporosis in women after menopause such as low weight, malnutrition (low BMI), early-onset menopause, and history of low weight during infancy/adolescence that affects the building of proper BMD. ${ }^{4,5}$

In Colombia, low weight in infancy in 2010 reached 13.2\% and malnutrition $3.4 \%$; these rates are greater in those who live in impoverished areas and/or with illiterate/not well-educated parents, where malnutrition hovers at $12.2 \%$. While these numbers are alarming, they are not as bad as in other Latin American countries like Peru, Ecuador, and Mexico. ${ }^{14}$ When addressing malnutrition in adults in Columbia, it has been shown that low weight is associated with young women, poverty, and those from African ancestry. ${ }^{14}$ 
There are very few studies showing the associations of poverty and osteoporosis, but the few there are (eg, $)^{5,6}$ have demonstrated that it is a factor for low BMD because it is associated with poor lifestyle choices such as sedentary activity, low nutritional food consumption, low-calcium diets, poor accessibility to health care, and low levels/quality of education. Studies have been conducted that show that people who live in the lowest class level in Colombia do not consume milk products daily, and that $41 \%$ do not eat fruit, $76.7 \%$ do not eat vegetables, and $18.5 \%$ do not eat meat. ${ }^{14}$ These findings show how there can be a serious risk of vitamin $\mathrm{D}$ and calcium deficiencies for those in this demographic. There are, of course, other reasons than economic, not to consume dairy products, such as lactose intolerance, gastrointestinal discomfort, and preconceived notions that consumption of dairy products is not as important for an adult as for a child. ${ }^{15}$

Reviewing our data, the presence of hypothyroidism was the most important risk factor for the development of osteoporosis. The association of these two diseases has not been well studied and there are few reports that confirm the connection. Vestergaard and Mosekilde, in a study population comprising 4473 women diagnosed with subclinical hypothyroidism with thyroid-stimulating hormone (TSH) levels above the 95th percentile, found an increased fracture risk with an interrater reliability of $2.35,{ }^{16}$ unlike what was reported by Grimnes et al, who tried to find a relationship between high TSH levels and its effect on the increase or decrease in BMD. ${ }^{17}$ They found that, in a patient with a value above the 97.5 th percentile, there was an increase in BMD at the femur neck. Although in contrast to the findings reported by Vestergaard and Mosekilde, the authors suggest in their discussion the possibility that quality of formed bone in women with hypothyroidism is lower than normal. ${ }^{17}$

A recent study evaluating the effects on bone exposed to high or low thyroid hormone levels in genetically manipulated mice demonstrated the effect of these conditions on bone mineralization. In both conditions was observed a mineralization deficit, in both cortical and trabecular bone. Measuring resorption and neoformation biomarkers suggests that the effect is caused by an increase in bone turnover in both conditions. ${ }^{18}$

Some authors have suggested that long-term treatment with levothyroxine may cause osteoporosis, but there is no evidence to support this theory. Some studies have shown no difference in bone density or fracture risk in those treated patients. Tagarra Lopez et al, in a retrospective study, found an increase in bone mass loss (67\% vs 35\%), osteopenia frequency ( $86 \%$ vs $54 \%$ ), and osteoporosis frequency
(14\% vs 5\%) in patients with subclinical hypothyroidism taking levothyroxine therapy compared with those who did not receive the thyroid hormone therapy, suggesting that thyroid hormone treatment may predispose to these changes. ${ }^{19}$ In our study, only $13 \%(5 / 38)$ of patients with osteoporosis received regular treatment with sodium levothyroxine at a dose of $63.3 \pm 32.6 \mu \mathrm{g}$ day, without significant differences between patients receiving and not receiving substitution.

There was no association between having a sedentary lifestyle and risk of osteoporosis. It is, however, important to show that $60 \%$ of the women evaluated in this study led a sedentary lifestyle, which suggests that this socioeconomic level does little physical activity, which may be due to lack of opportunities and social inequality. ${ }^{14}$ It is advisable to promote healthier lifestyles in such communities to alleviate comorbidities associated with these habits.

Vitamin D deficiency is one of the most directly related nutritional risk factors of osteoporosis, neuromuscular comorbidity, and osteoporotic fractures. There are extensive studies in developed countries showing the prevalence of vitamin D deficiency in healthy populations; geriatric care facilities; among those with chronic renal disease, hepatic disease, or neurological disease; and in those older than 65 years. Data show that the prevalence can vary from $11 \%$ up to $70 \% .{ }^{20}$ Multicentric studies in Latin America have shown that low vitamin D levels oscillate between $30 \%$ and $40 \%$.

An important limitation of this study was that there was no quantitative measurement of calcium in diet and levels of 25-hydroxycalciferol $(25-\mathrm{OH})$ in the blood, which could have given a better idea of whether calcium ingestion correlates with BMD.

In a study done in 105 Colombian patients with low BMD and osteoporosis, of which $80 \%$ were women around 66 years old, levels of $25-\mathrm{OH}$ averaged at $30.5 \mathrm{ng} / \mathrm{mL}$ ( $\mathrm{SD} \pm 16.1$; range $10.6-96 \mathrm{ng} / \mathrm{mL}$ ), and $69.5 \%$ had some degree of vitamin D deficiency: $45.7 \%$ were mild cases and $23.8 \%$ moderate cases; no severe cases were seen. This study showed the impact that vitamin $\mathrm{D}$ can have in our population and the need in public policy to encourage healthy lifestyles that promote its intake through dietary sources. ${ }^{21}$

The biggest strength of our study was the size of the sample and the fact that, to our knowledge, it is the first study done in premenopausal women in Latin America from impoverished backgrounds.

These preliminary results can be used to forge public policies on and strengthen the focus of health prevention services for fertile women from low socioeconomic areas. 


\section{Disclosure}

The authors report no conflicts of interest in this work.

\section{References}

1. Cundy T, Evans M, Roberts H, Wattie D, Ames R, Reid IR. Bone density in women receiving depot medroxyprogesterone acetate for contraception. BMJ. 1991;303(6793):13-16.

2. Kanis JA, Johnell O, Oden A, Jonsson B, De Laet C, Dawson A. Risk of hip fracture according to the World Health Organization criteria for osteopenia and osteoporosis. Bone. 2000;27(5):585-590.

3. Morales-Torres J, Gutiérrez-Ureña S; Osteoporosis Committee of PanAmerican League of Associations for Rheumatology. The burden of osteoporosis in Latin America. Osteoporos Int. 2004;15(8):625-632.

4. Ferrari S, Bianchi ML, Eisman JA, et al. Osteoporosis in young adults: pathophysiology, diagnosis, and management. Osteoporos Int. 2012; 23(12):2735-2748.

5. Navarro MC, Sosa M, Saavedra P, et al. Poverty is a risk factor for osteoporotic fractures. Osteoporos Int. 2009;20(3):393-398.

6. Handa R, Ali Kalla A, Maalouf G. Osteoporosis in developing countries. Best Pract Res Clin Rheumatol. 2008;22(4):693-708.

7. DANE. Colombian Population Census 2005. Web Page. Bogota, Colombia. Last updated Thursday, June 13, 2013; http://www.dane. gov.co/index.php?option=com_content\&view $=$ article \&id=307\&Itemi $\mathrm{d}=124$.

8. Díaz Curiel M, García JJ, Carrasco JL, et al. Prevalence of osteoporosis assessed by densitometry in the Spanish female population. Med Clin (Barc). 2001;116(3):86-88. Spanish.

9. Liu JM, Zhao HY, Ning G, et al. IGF-1 as an early marker for low bone mass or osteoporosis in premenopausal and postmenopausal women. J Bone Miner Metab. 2008;26(2):159-164.

10. Thomason K, West J, Logan RF, Coupland C, Holmes GK. Fracture experience of patients with coeliac disease: a population based survey. Gut. 2003;52(4):518-522.

11. Ahmed LA, Joakimsen RM, Berntsen GK, Fonnebo V, Schirmer H. Diabetes mellitus and the risk of non-vertebral fractures: the Tromso study. Osteoporos Int. 2006;17(4):495-500.
12. Burnham JM, Shults J, Weinstein R, Lewis JD, Leonard MB. Childhood onset arthritis is associated with an increased risk of fracture: a population based study using the General Practice Research Database. Ann Rheum Dis. 2006;65(8):1074-1079.

13. Legroux-Gerot I, Vignau J, Collier F, Cortet B. Bone loss associated with anorexia nervosa. Joint Bone Spine. 2005;72(6):489-495.

14. ICBF. Encuesta Nacional de la Situación Nutricional en Colombia ENSIN 2005. [National Survey of the Nutritional Situation in Colombia 2005]. http://juanfe.org/wp-content/uploads/2013/03/ENSIN-20051. pdf. 2005. Accessed on March 20, 2013.

15. Lagos Ruiz MJ, Rocio Montenegro Castillo Y, Niño Orbegoso GP, Barrera Perdomo MdP. Conocimientos, actitudes, practicas y consumo de calcio en un grupo de mujeres adultas: Bogota 2003-2004. Revista Cubana de Salud Publica. [Knowledge, attitudes, practices, and calcium intake in a group of adult women: Bogota from 2003 to 2004]. Journal of Public Health. 2005;31:211-216. Available from: http://scielo.sld. cu/scielo. Accessed June 20, 2013.

16. Vestergaard P, Mosekilde L. Fractures in patients with hyperthyroidism and hypothyroidism: a nationwide follow-up study in 16,249 patients. Thyroid. 2002;12(5):411-419.

17. Grimnes G, Emaus N, Joakimsen RM, Figenschau Y, Jorde R. The relationship between serum TSH and bone mineral density in men and postmenopausal women: the Tromsø study. Thyroid. 2008; 18(11):1147-1155.

18. Monfoulet LE, Rabier B, Dacquin R, et al. Thyroid hormone receptor beta mediates thyroid hormone effects on bone remodeling and bone mass. J Bone Miner Res. 2011;26(9):2036-2044.

19. Tárraga López PJ, López CF, de Mora FN, et al. Osteoporosis in patients with subclinical hypothyroidism treated with thyroid hormone. Clin Cases Miner Bone Metab. 2011;8(3):44-48.

20. Bolland MJ, Grey AB, Ames RW, et al. The effects of seasonal variation of 25-hydroxyvitamin D and fat mass on a diagnosis of vitamin D sufficiency. Am J Clin Nutr. 2007;86(4):959-964.

21. Gonzalez Devia D, Zuñiga Libreros C, Kattah Calderon W. Vitamin D insufficiency in adults patients with low bone mass and osteoporosis in the Fundacion Santa Fe de Bogota 2008-2009. Revista Colombiana de Reumatologia.17:212-218. http://www.scielo.org.co/scielo. php?script=sci_arttext\&pid=S0121-81232010000400003\&nrm=iso.
International Journal of Women's Health

\section{Publish your work in this journal}

The International Journal of Women's Health is an international, peerreviewed open-access journal publishing original research, reports, editorials, reviews and commentaries on all aspects of women's healthcare including gynecology, obstetrics, and breast cancer. The manuscript management system is completely online and includes

\section{Dovepress}

a very quick and fair peer-review system, which is all easy to use. Visit http://www.dovepress.com/testimonials.php to read real quotes from published authors. 